obvious loss of health, and, to judge from the work of Graham Lusk, his "efficiency" in the technical sense will not be affected. Work actually done will apparently be done at the same cost in Calories. We have, however, no certain knowledge as to how far that reduction can go (if it can occur at all) without affecting his ultimate capacity for work.

The review of modern experimental investigations with which the report opens well repays perusal as coming from authors highly qualified to appraise it from an independent point of view.

In connection with the experimental measurement of Calorie requirements, they do well to emphasise the point which Dr. Leonard Hill has recently made so clear-namely, that estimations made upon a man in a calorimeter at uniform temperature and in still air must not be applied in practice without proper qualifications. Vary the conditions, lower the external temperature, and especially increase the movement of air to which a resting man is exposed, and the demand goes up. It may be enormously increased.

Our knowledge concerning the energy requirement for the performance of external work is fully and very ably reviewed and appraised. It is shown that such data as those obtained by Benedict and Cathcart enable us to state with fair accuracy the increase in the demand for energy which goes with a given increase in work. This, however, applies only to work done within comparatively narrow limits. We have, for instance, no satisfactory data bearing on the cost of the more sedentary occupations.

In discussing the protein question the authors seem to be less at home. They do wrong, for example (though the point is perhaps of no great importance), in associating our modern conception of the metabolism of protein, involving, as it does, important chemical, as well as energetic, considerations, with the name of Rubner, who has given attention only to the all-important details of protein nutrition under compulsion born of other people's work. The authors justly pillory in the course of their historical discussion the vice of quotation at second hand; but it is just as bad to over-emphasise quotation from one particular original source unless its authority outweighs all others. On the protein question much more illuminating work and discussion have come from America and this country than from Germany.

The work embodied in this important document was carried out under the supervision of the Food Investigation Committee appointed by the Ministry of Munitions.

\section{THE AFFORESTATION QUESTION IN BRITAIN.}

$\mathrm{T}$ a previous article the present and future positions of the timber supplies of this country were considered. The afforestation question will now be briefly dealt with. Lord Selborne, in the House of Lords, recently asked whether the NO. 2546 , VOL. IOI]
Government was in a position to announce its decision on the report of the Forestry Sub-Committee of the Reconstruction Committee, mentioning the pressing necessity for replanting which existed throughout the country. Lord Peel replied that the Government had accepted the report of the Forestry Sub-Committee, and that a central authority for the United Kingdom would be set up and planting be proceeded with with the least possible delay. This announcement will be greeted with approbation by all acquainted with the urgent importance of the afforestation problem. Differences of opinion on administrative questions exist, but these are trivial compared with the main object in view-the afforestation of the waste lands of the country. Forestry in its general aspects is a branch of economic industry of which the British public has known very little in the past. It is not surprising that it should have remained in ignorance of its importance. For we have no forests in Britain in the sense in which the word is understood in Europe and elsewhere in the world. Ours are pretty woodlands. In the future it will be necessary to grow commercial woods, for the war has demonstrated unmistakably that, as a mere matter of safety in the case of emergency, we must have a reserve supply of timber and pit wood in the country.

It has been already shown that we have to face the probability of all our commercially exploitable woodlands being cut out either during the war or in the years immediately following the peace. In I9I 4 we had $3,000,000$ acres of woods in Britain. On a rough estimate half of these will disappear, and the areas occupied by them be replanted. This work is more a matter for the proprietors, who have received a high price for material which in many cases was almost unsaleable before the war. In some instances Government assistance may prove necessary. These fellings will not be all to the bad, since considerable areas, commercially worthless in pre-war days, owing to the poor methods on which they were grown, will have been cut out.

But these $I \frac{1}{2}$ million acres do not affect the main afforestation problem before the nation. Since the outbreak of war, Ministers and others. have been wisely preaching thrift and conservation of the national resources. There are some $16 \frac{3}{4}$ million acres of mountain and heath land in Great Britain, much of it bringing in a very small return per acre, from $2 s$. $6 d$. down to a few pence.

Some of this land is above the limit in elevation of tree growth; other parts may prove reclaimable for agriculture. Land which is utilisable. for the production of food should not be afforested. But there remains, so far as an estimate can be formed, at least some $3,000,000$ to $5,000,000$ acres which can be made to produce, in the national interests, a higher return both in money and general utility when placed under tree crops. Moreover, on these large areas of waste landfor, in the sense that they are not being put to their best use in the interests of the community, 
they are waste lands-it will be possible to demarcate blocks of a size capable of being worked on a commercially profitable scale, with systematic fellings which will guarantee a continuity in supply of material, reduce the cost of extraction of the material, cover the cost of upkeep, and yield a profit. Such areas of forest will maintain a larger population on the land, since forests require more people to look after them than the pasturing of sheep. They will also result in the employment of a considerable head of population in industries which arise in a wooded countrye.g. saw-mills, pulp-mills, furniture and box factories, etc.

The afforestation of these lands is not going to prove easy. The rich layers of soil they previously possessed have been long since dispersed, and the young plantations, bereft of shelter, will have to stand considerable exposure. We must be prepared for small crops during the first rotation. But even these should give a higher return than much of the land is at present yielding. Its afforestation will then be making a better use of the wastes, provide our descendants with a necessity for their industries, and give them a reserve for an emergency.

The land is at present in private ownership. An Act will doubtless be necessary in order to give the State the powers to acquire, in the public interest and at its marketable value, such land as it may deem necessary for reclamation for agriculture or for afforestation. But so far as afforestation is concerned it is unlikely that Government would be obliged to have recourse to the Act to effect the purpose in view. The acquisition of land by Government is undesirable if only on account of the friction it might give rise to. The better method of procedure will be by way of leasing areas from proprietors for a rotation (seventy years) or two rotations (I40 years). The Development Commissioners have drawn up schemes on these lines. They offer to take over land from a proprietor on an ordinary lease and plant it up from their own funds (in conjunction with the Boards of Agriculture), the proprietor being given a small share of the proceeds from the woods, in addition to his annual rental; or, as an alternative, the proprietor to forgo any rental for his land, which will be planted up with money provided by the Commissioners, the two parties dividing the profits on a basis fixed by the amount of outlay incurred by each in the business. These offers appear to be mutually advantageous, and should result in the land required being obtained.

The selection of the land to commence operations upon can be left to the Forestry Advisers. These officers have the whole country divided up between them; they have been at work several years, and will be acquainted with the most favourable areas in their respective districts.

Now as to the cost of the undertaking. All figures have at present a problematical ring. But an all-round sum of $3 l$. per acre for the planting of the felled-over areas ( $1 \frac{1}{2}$ million acres), and NO. 2546 , VOL. IOI] 4l. for the waste land (rabbit netting is not included, as rabbits will have to be exterminated in the planting areas), should be near the mark; or $24,000,000 l$., some $1,500,000 l$. to $2,000,000 l$. being provided by the proprietors. The amounts payable on the leases and upkeep, as also the more difficult problem of compensation for the removal of sheep stock in some cases, will be additional. Questions of space render it impossible to go into these matters. But they are details, though important ones, of the broad general scheme.

This area of $6 \frac{1}{2}$ million acres should give, under skilled management, 455,000,000 cubic feet of all classes of timber, or about three-fourths of the I9I3 imports. It will only prove a safety margin, for our pre-war consumption was increasing annually, and available imports, at a reasonable price, will decrease in the future.

E. P. Stebbing.

\section{AGRICULTURAL EDUCATION IN SOUTH AFRICA AND AUSTRALIA.}

THE South African Journal of Science for lecember last contains two articles on the organisation of agricultural education in South Africa and Australia respectively which deserve some notice, if only on account of the contrasts which they bring into prominence. Whereas in Australia the organisation seems to be complete from the bottom to the top of the ladder-from the elementary school to the university and research station-in South Africa, on the other hand, the conditions approximate to those existing in this country, where we have sporadic agricultural colleges catering more for the teacher of agriculture than for the farmer, and no effective link with the organisation of education generally.

In Australia the provision of what may be described as intermediate agricultural education appears to have reached a remarkable pitch of efficiency. The "colleges" there, which we should describe as "farm schools," aim at fully equipping the young farmer for the business of his life in a new country. Among the subjects taught are carpentry, saddlery, butchery, engineering, etc., and the writer of the article speaks of inspecting horseshoes, chisels, cultivator tines, complete sets of saddlery, all made by the students themselves. When we learn further that the lands of one of these "colleges" extend to 3500 acres, that upwards of $2000 l$. worth of stock is sold annually, and that $\mathrm{r}_{30}$ horses are maintained, we can form some idea of the seriousness of purpose with which the technical training is pursued.

Scientific progress is not neglected. In New South Wales alone there are fifteen State experimental farms, where the special problems of Australian agriculture are being systematically attacked. One result of considerable scientific interest may be noticed. It appears to have been established that, generally speaking, Australian conditions do not demand the use of nitrogenous fertilisers, and in a Government publication is found the remarkable statement that the Austra- 